\title{
The Impact of Green Marketing Components on Corporate Image of Green Certified Hotels in Sri Lanka
}

\author{
B.A.G.S.N. Wijewardena ${ }^{1} \&$ U.L. Herat ${ }^{2}$ \\ ${ }^{1,2}$ Department of Business Management \\ Faculty of Business Studies \& Finance \\ Wayamba University of Sri Lanka \\ Kuliyapitiya, \\ SRI LANKA. \\ $\underline{\text { sureshnilupulw@gmail.com }}{ }^{1}, \underline{\text { umangi@wyb.ac.lk }}$
}

\begin{abstract}
The green concept is becoming a popular concept in today's world as nowadays people is more concern on environmentally friendly products and services. With that trend many industries are encouraged to adopt green marketing concept in their activities. When applying green marketing practices, the Hotel industry in Sri Lanka has a key role to play, as it is considered as the largest resource consuming industry in Sri Lankan context. There have been limited previous researches specifically studied in Sri Lanka on the subject of green marketing in the hotel industry. Most of the studies are available in other countries and in various industries but not in Sri Lankan context, hence there is a need in empirical evidences to examine the impact of green marketing components on corporate image. Therefore, this study intended to examine the impact of green marketing components on corporate image of green certified hotels in Sri Lanka. After critical review of literature, three factors, green/eco-friendly activities, corporate communication of green practices and green image were selected as the independent variables. The primary data were collected from 384 customers who had been visited green certified hotels in Sri Lanka by using a generalized questionnaire and convenience sampling technique. Data analysis was done by using multiple regression analysis. The findings proved green/eco-friendly activities, corporate communication of green practices and green image factors positively and significantly impact on corporate image of green certified hotels in Sri Lanka. Thus it emphasizes hoteliers in Sri Lanka should increase the eco-friendly services, green label products, and increase the energy conservation in order to increase their corporate image Therefore, the information of this study will be more beneficial to managers of green certified hotels in Sri Lanka in order to retain and attract more eco tourists to Sri Lanka by improving their corporate image using these green marketing components and moreover the findings will be vital for future researchers to extend their studies in green marketing and corporate image in hotel industry.
\end{abstract}

Keywords: Corporate Communication of Green Practices, Corporate Image, Green/eco-friendly Activities, Green Image, Green Marketing, 


\section{INTRODUCTION}

The concept Sustainability has become a global matter of concern in today's world. When considering the concept of sustainability, the term Environmentally friendly /ecofriendly, come into the practice as it is a term which comes under the concept of sustainability (Adil, 2017). With that today, the world is shifting towards the green concept that is primarily connected with the eco concept, which focuses on enhancing resource efficiency while reducing the effect on human health, productivity and the environment. (Burchell \& Cook, 2006). Nowadays that green concept has become a matter of concern in every field and it has become one of the most important topic in academic research (Hartmann, et al.,) as well. There are number of studies that emphasized the benefits of implementing green marketing practices to their organizations. According to (Ottman, 1994), green marketing supports organizations in different ways, such as having a positive effect on corporate image and thus consumer intention to revisit to the firm, increasing operational efficiency, competitive advantage, helping the company to become more effective, improving brand value, provide platform for innovation, help attract and retain employees, cut costs and strengthen stakeholder relations. Green marketing affects all areas of economy, it does not just lead to environmental protection but it also creates new market and job opportunities. Companies that are environmental concern stand a chance of gaining many satisfied and loyal customers.
"Green Marketing" is a holistic management process that is accountable for meeting customer and society requirements and needs in a profitable and sustainable manner (Do Paco \& Raposo, 2009). Also (Sharmila, 2016), mentioned that environmental problems are one of the reasons why the green marketing emerged. Society became more concerned with natural environment and for eco-friendly purchases, so that business has started to modify their behavior in order to address societies ${ }^{\text {ee }}$ new concern (Choudhary \& Gokarn, 2013). Therefore, it is vital to conduct a research to find out the impact of green marketing components on cooperate image of the hotel industry in Sri Lanka as it is the largest resource consuming industry (energy, water, material, and food) and generating disproportionate amount of waste.

\subsection{Research Problem}

Like the many industries in today $\mathrm{s}$ world, Hotel industry is also considering to be more eco-friendly, as it is a significant consumer of energy, water and other non-durable products (Manaktola, 2007). According to annual statistical report of Tourist Board (2017) Sri Lanka, hospitality sector known as the largest resource consuming industry (energy, water, material, and food) and generating disproportionate amount of waste. According to Wadippuliarachchi et al., 2015 Sri Lanka is currently experiencing less number of eco-tourists, and it is less than $1 \%$ over last decade, that is mainly due to the poor practice of the green concept by the eco-hoteliers. Therefore, the hotels in Sri Lankan 
hotel industry has a vital role to play in adopting green concept in their activities to attract eco tourists to their hotels.

Researches and managers know relatively less about how green marketing improve corporate image (Yadav, et al., 2016). According to Burchell \& Cook, 2006, although green marketing/eco-friendly initiatives are gaining popularity as a strategic initiative in the hospitality sector, there is a lack of studies that have explored the effect of green marketing on the corporate image. Also, according to Sivesan, et al., 2013 , the studies on green marketing are in the early stages even in developed countries and there is a need of doing research on green marketing. Moreover, the concept sustainability is more popular in the developed nations, but there is a need of doing research to establish the level of understanding the green concept in the developing nations, as the majority of population belongs to developing nations (Manaktola, 2007).

Though there are many hotels in Sri Lanka only 13 hotels were considering as the LEED hotels (Leadership in Energy and Environmental Design), which is a globally recognized symbol of sustainability achievement, where it is a structured assessment of the sustainability performance of travel and tourism businesses and given for their supply chain partners in Sri Lanka. Therefore, when considering the above gaps, it is evident that there is need for identification of the impact of green marketing components on corporate image of green certified hotels in Sri Lanka.

\subsection{Research Objectives}

1. To investigate the positive and significant impact of green/ecofriendly activities on corporate image of green certified hotels in Sri Lanka.

2. To investigate the positive and significant impact of corporate communication of green practices on corporate image of green certified hotels in Sri Lanka.

3. To investigate the positive and significant impact of green image on corporate image of green certified hotels in Sri Lanka.

\subsection{Contribution of the paper}

This research study is important to managers of hotels in Sri Lanka in order to retain and improve the arrivals of eco tourists to Sri Lanka by improving their corporate image using green marketing. Since Sri Lanka is a country with cultural and natural diversity, it has the ability to develop the green concept in hotel industry better than other destinations (Wadippuliarachchi, et al., 2015).

Therefore, this study guide managers of hotel industry to identify which green marketing components should be used to create a better image of green certified hotels in Sri Lanka, hence it is needed to conduct this research of investigating the impact of green marketing components on corporate image of green certified hotels in Sri Lanka. 


\subsection{Literature Review}

\section{Corporate image}

Corporate image can be defined as the combination of various variables that indicate and communicate the corporate identity (Karaosmanoglu \& Melewar, 2006). It is a person's private assessment of the organization that includes a set of views, emotions and feelings (Dowling, 2001) The word "corporate image" is frequently used with the word "corporate reputation" as all components of the company viewed by the customers. (Kang \& Yang, 2010) Researchers have proved that by developing a favorable image, a firm can create a positive attitude towards its product and services and it is also regarded as an organization's strategic resource (Balmer, 2012).

It is proved in many articles that business image plays a critical role in the consumer's buying behavior. Existing empirical studies indicate that the corporate image of a hotel also contributes to a more positive behavioral intention (i.e. revisit intention) (Han \& Kim., 2010): (Han, et al., 2010). Behavioral intention is described as the likelihood of people engaging in a particular undertaking and when behavioral intentions are positive, a high probability of a customer revisiting the hotel and spreading positive word-of-mouth is high also in long run, hence that will contribute to increase the profitability of hotels (Jani, 2013)

\section{Green/ Eco-friendly Activities.}

Organizations' environmentallyfriendly activities reveal environmental concerns and are regarded to be the significant efforts made by organizations, and CSR activities are properly used to contribute to improving the image and market position of the companies (Fraj-Andres \& E., 2012) Organizations that invest in environmental issues can be a better picture and represent the concern of the organization for the good of society (Chen, 2010) pointed out that the environmental participation of company organizations helps an organization to build its corporate image.

\section{Corporate communication of green practices}

Corporate communication of green practices provides a structure for the efficient coordination of all inner and external communication with the aim to create and maintain a positive reputation for stakeholder organizations that are dependent on the organization (Cornelissen, 2008) Marketers should emphasize the correct and efficient communication of hotel green / ecological tasks and communication is a very significant element to the achievement of environmentally friendly products / services. (Pickett \& Kangun, 1995).

\section{Green Image}

According to (Chen, 2010) Green Image is "a set of perceptions of brand in consumer's mind that is linked to environmental commitment and environmental concerns". Many organizations engage in eco-friendly activities and create a green image with environmental organizations (Jani, 2013). Green image is vital for businesses particularly in the context 
of common consumer awareness of environmentalism and serious global environmental protection laws (Chen, 2010) There has also been a fact that third parties can enhance the general picture of hotels by certifying environmental standards (Choudhary \& Gokarn, 2013).

\section{METHODS}

\subsection{Research approach}

The deductive approach is used by the researcher for the present study. In this quantitative method, it was identified research gap and after that hypotheses were built for further analysis. Then hypotheses were tested and based on those conclusions, recommendations were provided.

\subsection{The Conceptual Model}

After a critical review of literature, the developed conceptual model can be depicted as follows

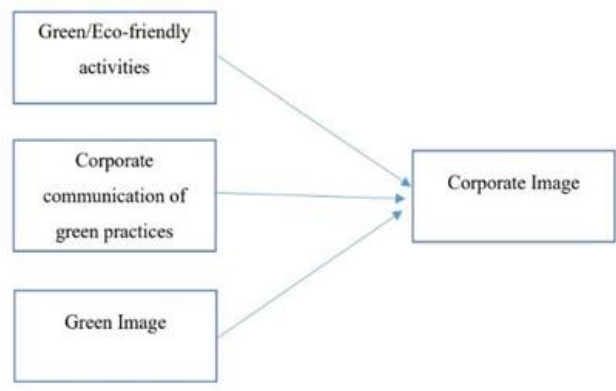

Figure 1. Conceptual Framework

\subsection{Hypotheses}

The following hypotheses are formulated to findout the answer for the research questions of what extent the green/eco-friendly activities, corporate communication of green practices and green image affects the corporate image of green certified hotels in Sri Lanka.

$\mathrm{H} 1$ : There is a positive and significant impact of green/eco-friendly activities on corporate image of green certified hotels in Sri Lanka

$\mathrm{H} 2$ : There is a positive and significant impact of corporate communication of green practices on corporate image of green certified hotels in Sri Lanka

H3: There is a positive and significant impact of green image on corporate image of green certified hotels in Sri Lanka

\subsection{Population and Sampling technique}

The target population of this study are the customers who had been visited green certified hotels in Sri Lanka. Since the population is unknown for this research study the formula which was developed by Cooper \& Schindler, 2008 was used to calculate the sample size as 384 . Under the nonprobability sampling technique, convenience method was used to collect data among those customers.

\subsection{Data Collection and Analysis}

In this study primary data were collected through a generalized questionnaire as an online survey by using the Facebook as a communication tool, because many researchers have proved that Facebook as an effective mean of data collection for its high response rate and increase relevance over time as a communication tool. (Balmer, 2012). 
In this study, the multiple linear regression was used to investigate the impact of green marketing components on corporate image of green certified hotels in Sri Lanka.

Reliability was examined on all items included in in the questionnaire by using the cronbach's alpha value.

\section{RESULTS}

The Cronbach's alpha value indicated that all three variables are within the acceptable range of consistency and it can be depicted as follows.

Table 1. Cronbach's Alpha Values

\begin{tabular}{|l|l|l|l|}
\hline Variable & $\begin{array}{l}\text { Cronbach's } \\
\text { Alpha }\end{array}$ & $\begin{array}{l}\text { Number } \\
\text { of Items }\end{array}$ & Strength \\
\hline $\begin{array}{l}\text { Green/eco- } \\
\text { friendly } \\
\text { activities }\end{array}$ & 0.806 & 4 & Accepted \\
\hline $\begin{array}{l}\text { Corporate } \\
\text { Communication } \\
\text { of green efforts }\end{array}$ & 0.865 & 4 & Accepted \\
\hline Green Image & 0.795 & 5 & Accepted \\
\hline Corporate Image & 0.702 & 5 & Accepted \\
\hline
\end{tabular}

Further testing assumptions of multivariate analysis of linearity, homoscedasticity and normality ensured the suitability of dataset. The multicollinearity, Variance Inflation Factor (VIF) of all variables and tolerance values for all the observed variables are greater than 0.10 , which are in acceptable range.

\subsection{Bivariate Analysis}

With the intention of identifying the relationship among variables in terms of its significance, direction, and strength of association Pearson correlation analysis was used.
Table 2. Results of the Correlation Analysis

\begin{tabular}{|c|l|r|r|r|r|}
\hline \multicolumn{7}{|c|}{ Correlations } \\
\hline \multicolumn{2}{|c|}{} & GA & CC & GI & CI \\
\hline GA & $\begin{array}{l}\text { Pearson } \\
\text { Correlation }\end{array}$ & 1 & & & \\
\hline CC & $\begin{array}{l}\text { Pearson } \\
\text { Correlation }\end{array}$ & $.718^{* *}$ & 1 & & \\
\hline GI & $\begin{array}{l}\text { Pearson } \\
\text { Correlation }\end{array}$ & $.737^{* *}$ & $.717^{* *}$ & 1 & \\
\hline CI & $\begin{array}{l}\text { Pearson } \\
\text { Correlation }\end{array}$ & $.757^{* *}$ & $.692^{* *}$ & $.746^{* *}$ & 1 \\
\hline
\end{tabular}

**. Correlation is significant at the 0.05 level (2tailed).

According to the Table 2 it indicated that all the variables are positively and significantly related to each other. The results of the bivariate analysis provide a firm basis for continuing further analysis.

\subsection{Regression Analysis}

\section{Model Summery}

Table 3. Results of the Model Summery

\begin{tabular}{|c|c|c|c|c|}
\hline Model & $\mathrm{R}$ & $\begin{array}{c}\mathrm{R} \\
\text { Square }\end{array}$ & $\begin{array}{c}\text { Adjusted } \\
\text { R Square }\end{array}$ & $\begin{array}{c}\text { Std. } \\
\text { Error of } \\
\text { the } \\
\text { Estimate }\end{array}$ \\
\hline 1 & $.814^{\mathrm{a}}$ & 0.663 & 0.659 & 0.29370 \\
\hline
\end{tabular}

The “Adjusted R square' value of the table explains the multiple regression coefficient, which is 0.659 , and it shows a positive relationship between independent variables and dependent variable. The "Adjusted $\mathrm{R}$ square' value indicates how much of the dependent variable, Corporate image 
can be explained by the independent variables of green/eco-friendly activities, corporate communication of green practices and green image. According to the above table, $81.4 \%$ of Corporate Image can be explained by the above mentioned four independent variables.

\section{Analysis of Variance (ANOVA)}

Table 4. Results of the Analysis of Variance

\begin{tabular}{|c|c|c|c|c|c|}
\hline Model & $\begin{array}{c}\text { Sum of } \\
\text { Squares }\end{array}$ & If & $\begin{array}{c}\text { Mean } \\
\text { Square }\end{array}$ & F & Sig. \\
\hline Regression & 48.182 & 3 & 16.061 & 186.197 & $.000^{\mathrm{b}}$ \\
Residual & 24.497 & 284 & 0.086 & & \\
Total & 72.679 & 287 & & & \\
\hline
\end{tabular}

Based on the output in ANOVA table p-value of under the SPSS (0.000) is less than the critical $\mathrm{p}$ value $(0.05)$ hence can be concluded the model is statistically significant.

\section{Multiple Regression Analysis}

Table 5. Coefficients

\begin{tabular}{|c|c|c|c|c|c|}
\hline \multirow[t]{2}{*}{$\begin{array}{l}\overrightarrow{\mathrm{s}} \\
\stackrel{\vec{a}}{\mathrm{a}}\end{array}$} & \multicolumn{2}{|c|}{ 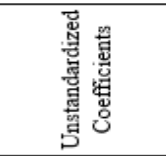 } & 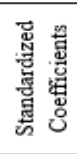 & \multirow[t]{2}{*}{-} & \multirow[t]{2}{*}{ 嵒 } \\
\hline & $m$ & 总总 & 急 & & \\
\hline 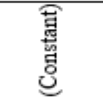 & 1.472 & 0.120 & & 12.301 & 0.000 \\
\hline 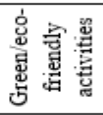 & 0.288 & 0.042 & 0.381 & 6.846 & .000 \\
\hline 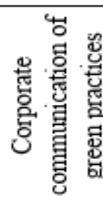 & 0.116 & 0.036 & 0.173 & 3.204 & .002 \\
\hline 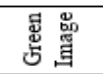 & 0.267 & 0.043 & 0.341 & 6.143 & .000 \\
\hline
\end{tabular}

$C I=\beta 0+\beta 1(G A)+\beta 2(C C)+\beta 3$

(GI) $+€$

$\mathrm{Y}=1.472+0.381(\mathrm{GA})+0.173(\mathrm{CC})$

$+\mathbf{0 . 3 4 1}(\mathrm{GI})$

$\mathrm{CI} / \mathrm{Y}=$ Corporate Image

$\beta 0=$ Intercept of the equation

GA/X1 = Green/eco-friendly

activities

$\mathrm{CC} / \mathrm{X} 2$ = Corporate communication of green practices

$\mathrm{GI} / \mathrm{X} 3=$ Green Image

$€ \quad=$ Error

$\beta$ value represents the extent to which the value of the independent variable contributes to the variance of the dependent variable.

The constant has the unstandardized $\beta$ value as 1.472. It indicates the value of the corporate image, when all of the independent factors remain constant.

The main objective of this study was to investigate the impact of green marketing components on corporate image of green certified hotels in Sri Lanka. Therefore, the first objective was to investigate the impact of green/eco-friendly activities on corporate image of green certified hotels in Sri Lanka. With $\beta$ coefficient value of 0.381 and p-value of 0.000 , which is less than 0.05 . This shows that green activities give a positive \& significant impact on corporate image of the hotels in the minds of the consumer with accepting $\mathrm{H} 1$.

The second objective was to examine the impact of corporate communication of green practices on corporate image of green certified hotels in Sri Lanka. The $\beta$ coefficient of 0.173 and $p$-value of 0.002 , which is less than 0.05 , corporate 
communication of green practices was proven to bring the positive \& significant impact to corporate image of the green certified hotels in the minds of the consumers in Sri Lanka with accepting $\mathrm{H} 2$.

According to third objective in this study, it should be investigated the impact of green image on corporate image of green certified hotels in Sri Lanka. With $\beta$ coefficient value of 0.341 and $p$ - value 0.000 , it can be identified there is a positive \& significant impact of green image on corporate image of green certified hotels in Sri Lanka while accepting H3

A total of 384 survey questionnaires were distributed to the target consumers of which 288 acceptable questionnaires were received back from them with the effective response rate of $75 \%$. Considering major findings of the study, it can be identified green/eco-friendly activities, corporate communication of green practices and green image are positively \& significantly impact on corporate image of green certified hotels in Sri Lanka.

\section{DISCUSSION}

Green practices are one of the significant concepts among several industries and Sri Lankan hotel industry also no omission. When society is more concern on environmentally friendly products and services the hotel industry in Sri Lanka has a key role play in applying green marketing components as it is the largest resource consuming industry in Si Lankan context.

The major purpose of this study is to investigate the impact of green marketing components on corporate image of green certified hotels in Sri Lanka. According to the analysis, it was found that green/eco-friendly activities, corporate communication of green practices and green image factors positively and significantly impact on corporate image of green certified hotels in Sri Lanka.

\section{CONCLUSION}

There have been limited previous researches specifically studied in Sri Lanka on the subject of green marketing in the hotel industry. Most of the studies are available in other countries and in various industries but not in Sri Lankan context. Accordingly, the researcher attempted to fill that empirical gap from this study.

The findings of the study are very useful for the marketers and managers in the hotel industry to give their attention on green/eco-friendly activities in hotels in order to attract more eco-tourists to Sri Lanka. Hoteliers should increase the ecofriendly services, increase the use of products which are certified with green label in order to increase their corporate image.

According to this study as it indicated that there is a positive \& significant relationship between corporate communication of green practices on corporate image, hotels should 
communicate their green practices through a varied channel such as electronic media, printing and client relations. Also they can concentrate on marketing and the planning of their green practices and can get the support from the sponsors for the events which are related to environment.

Since it indicated that green image also has a positive and significant impact on corporate image, hoteliers should give their consideration on green marketing in order to create a green image for the success of green marketing in Sri Lankan hotel industry.

Although the present study has added to the existing body of knowledge in the hospitality sector, more specifically in a developing country like Sri Lanka, the study has several limitations.

In the present research, three components, were only selected to test the impact on corporate image. In future research, characteristics such as the green partnership and employee attitudes may also be taken into account, which could influence the corporate image of hotels. In this research, the sample was limited to a total of 288 and it is recommended for future researchers to select large number of customers using other sampling technique.

\section{REFERENCES}

Adil, F., 2017. Renovation for the Sustainability. Journal of Clearner Prduction.

Balmer, J., 2012. "Strategic corporate brand alignment: perspectives from identity based views of corporate brands. European Journal of Marketing, 8(46), pp. 1064-1092.

Burchell, J. \& Cook, J., 2006. It's good to talk? Examining attitudes towards corporate social responsibility dialogue and engagement processes. Businss Ethics: A European Review..

Chen, Y., 2010. The drivers of green brand equity: green brand image, green satisfaction. Journal of Business Ethics, 93(2), pp. 307319.

Choudhary, A. \& Gokarn, S., 2013. GREEN MARKETING: A MEANS FOR SUSTAINABLE DEVELOPMENT. International Refereed Research Journal.

Cooper \& Schindler, 2008. Business research methods, New York: McGraw-Hil.

Cornelissen, J., 2008. Corporate Communication. London: Sage.

Do Paco \& Raposo, M. a., 2009. "Identifying the green consumer: a segmentation study. Journal of Targeting, Measurement and Analysis for Marketing.

Dowling, G., 2001. Creating Corporate Reputation, Oxford: Oxford University Press.

Fraj-Andres \& E., L.-P., 2012. Company image and corporate social responsibility:reflecting with SMEs ${ }^{\text {ee }}$ managers. Marketing Intelligence and Planning, 30(22), pp. 266-280. 
Han \& Kim., 2010. An investigation of green hotel customers' decision formation.. International Journal of Hospitality Management.

Han, L., Schneiter \& Chang., 2010. Understanding how consumers view green hotels: how a hotel's green image can influence behavioural intentions.. Journal of Sustainable Tourism..

Hartmann, P., Ibanez, V. \& \& Sainz, F., n.d. Green branding effects on attitude: functional versus emotional positioning strategies. Marketing Intelligence \& Planning, Volume 23, pp. 9-29.

Jani, D., 2013. Personality, social comparison, consumption emotions, satisfaction, and behavioral intentions. International Journal of Contemporary Hospitality Management.

Karaosmanoglu, E. \& Melewar, T., 2006. Corporate communications, identity and image: a research agenda. Journal of Brand Management,, pp. 196-206.

Manaktola, K. a., 2007. Exploring consumer attitude and behaviour towards green practices in the lodging industy in India. International Journal of Contempoary Hospitality Management.

Ottman, J., 1994. Green Marketing. Lincolnwood: NTC Business Books..
Pickett \& Kangun, 1995. An examination of the conserving consumers: implications for public policy formation on promoting conservationbehaviour, $\quad$ s.l.: Environmental Marketing.

Sharmila, 2016. A study on importance and need of green marketing. International Journal of Academic Research and Development, 1(9), pp. 102-106. .

Sivesan, S., Achchuthan, S. \& U. R., 2013. Green Marketing Practicesand Customer Satisfaction: A Special Reference to Leather Goods. Global Journal of Management and Business Research Accounting and Auditing, .

Wadippuliarachchi, R. S., Yajid, M. S. \& Khatibi, A., 2015. Eco-Tourism Practicein Sri Lankan Eco Resorts: An Analysis of Satisfaction and Behavioural Intention of Eco Tourists. International Journal of Business and SocialScience.

Yadav, R., Dokania, A. K. \& \& Pathak, G. S., 2016. The influence of green in building corporate image : Evidences from hospitality industry in a developing nation. International Journal of Contemporary Hospitality Management. 